\title{
Effects of Olive Oil and Grape Seed Oil on Lipid Profile and Blood Pressure in Patients with Hyperlipidemia: A Randomized Clinical Trial
}

\author{
Fatemeh Kaseb ${ }^{1}$, Akram Naghdipour Biregani ${ }^{2 *}$ \\ ${ }^{1}$ Yazd Obesity Center, Shahid Sadoughi University of Medical Sciences, Yazd, Iran \\ ${ }^{2}$ Department of Paramedicine, Shahid Sadoughi University of Medical Sciences, Yazd, Iran \\ Email: "naghdipour86@yahoo.com
}

Received 23 May 2016; accepted 6 July 2016; published 9 July 2016

Copyright (C) 2016 by authors and Scientific Research Publishing Inc. This work is licensed under the Creative Commons Attribution International License (CC BY). http://creativecommons.org/licenses/by/4.0/

(c) (i) Open Access

\section{Abstract}

Background and Aims: Hyperlipidemia is one of clear risk factors of diabetes. Regarding its importance, this study was designed to compare the effects of olive oil and grape seed oil on serum lipids and blood pressure in patients with hyperlipidemia in 2015. Methods and Results: In this clinical trial, 60 patients with hyperlipidemia who met inclusion criteria were recruited. Subjects were randomly assigned 3 groups: 1) consume $20 \mathrm{ml} /$ day refined olive oil; 2) consume $20 \mathrm{ml} / \mathrm{day}$ grape seed oil; 3 ) the control group received no oil. The study period was six weeks. All participants were under Step I diet. Height and weight measurements were taken by Seca scale. Blood pressure, total cholesterol, high-density lipoprotein, triglyceride and fasting blood sugar were measured at baseline and after 6 weeks by standard methods. Low-density lipoprotein levels were calculated by the Friedewald's formula. Data were analyzed with ANOVA test in SPSS software version 16.0. Sixty participants (36 female and 24 male) with the average age of $47.5 \pm 9 \mathrm{y}$ and the mean body mass index of $31.78 \pm 5.41 \mathrm{~kg} / \mathrm{m}^{2}$ had completed the study. Olive oil intervention decreased systolic blood pressure significantly compared to grape seed oil group $(P=0.01)$. Triglyceride was significantly decreased in olive oil and also triglyceride groups $(P=0.02$ and 0.004, respectively). Conclusion: Overall, the effects of olive oil and grape seed oil were better than control group. However, we suggest the substitution of dietary lipids with olive oil because of its more beneficial effects. Registration number for clinical trial: IRCT2014070218329N1 registration code in Iran Clinical Trial site.

${ }^{*}$ Corresponding author.

How to cite this paper: Kaseb, F. and Biregani, A.N. (2016) Effects of Olive Oil and Grape Seed Oil on Lipid Profile and Blood Pressure in Patients with Hyperlipidemia: A Randomized Clinical Trial. Food and Nutrition Sciences, 7, 682-688. 


\section{Keywords}

\section{Olive oil, Grape Seed Oil, Lipid Profile, Blood Pressure, Hyperlipidemia}

\section{Introduction}

Hyperlipidemia has a quite clear role in the etiology of coronary heart disease [1] [2]. Because of the low prices and few side effects, natural strategies like diet therapy can be used effectively to deal with the problem hyperlipidemia. For instance, the type of fatty acids in diet has a major role in cardiovascular health [3].

Some researchers are considered to replacing saturated and trans-fats with Mono Unsaturated Fatty Acids (MUFAs) containing oils such as olive oil [4]. They have emphasized the usefulness of olive oil and its correlation with lower prevalence of coronary disease. Furthermore, phenolic compounds of olive oil are also thought to contribute to its health benefits [5].

In other hand, the results of other researches have mentioned the role of replacement of saturated fatty acids with polyunsaturated fatty acids (PUFAs) [6]. Grape seeds are a rich source of PUFAs and phenolic compounds and it uses for the prevention and treatment of cardiovascular diseases from long ago.

A lot of studies were done in this regard, but not correctly specified the most appropriate way to reduce trans and saturated fatty acids is replacing it with MUFA or PUFA [6]-[8]. This study was designed to compare the effects of olive and grape seed oil on metabolic responses in hyperlipidemic patients.

\section{Methods}

\subsection{Study Population}

This double blind clinical trial was performed with parallel design on 70 eligible hyperlipidemic patients referred to Obesity Center of Shahid Sadoughi University of medical sciences Specialty and Subspecialty Baghaeipour Clinic by public advertisement in 2015. Individuals were enrolled in the study included subjects 30 60 years of age, with at least one of imbalanced blood lipid indices [including total cholesterol (TC) $\geq 200$ $\mathrm{mg} / \mathrm{dl}$, high density lipoprotein (HDL) $\leq 40 \mathrm{mg} / \mathrm{dl}$, low density lipoprotein (LDL) $\geq 130 \mathrm{mg} / \mathrm{dl}$ and triglyceride (TG) $\geq 150 \mathrm{mg} / \mathrm{dl}$, without a personal history of cardiovascular, hepatic and renal disease and intake of antioxidant supplements during the study.

\subsection{Study Design}

After obtaining informed consent, subjects randomly assigned to 3 groups using the table of random numbers by a statistician: 1) Consuming $20 \mathrm{ml} /$ day refined olive oil (OO) (two teaspoonful in the morning and 2 in the afternoon); 2) Consuming $20 \mathrm{ml} /$ day refined grape seed oil (GSO); 3) The control group will receive no oil. The Intervention period was 6 weeks. The subjects take low calorie Step I diet [9] recommended by a nutritionist. At baseline refined olive and grape seed oil (that were colorless and odorless) poured in coded graded containers by a person who was not participate in the process of the study. Researchers who conducted the study and analyzed the data of the study were not generally aware which code is assigned to each oil.

Olive oil and grape seed oil were used respectively produced by Kokab Olive Oil Company (Qazvin, Iran) and DIVO Company (Italy). The study protocol was approved by the Ethics Committee of Shahid Sadoughi University of medical sciences, Yazd, Iran and recorded in Iran Clinical Trial site with IRCT2014070218329N1 registration code. Written consent was obtained from all participants.

\subsection{Clinical Analysis}

Blood pressure (BP) was recorded at baseline and after 6 weeks with a standard mercurial column sphygmomanometer (Model FC-110Deluxe, Focal Corporation, Japan) after 5 minutes resting in a seated position.

All patients were sent to the Yazd diabetic research center to do experiments at baseline and the end of intervention. Blood samples were collected and TC, HDL, TG and fasting blood glucose (FBS) were measured at baseline and after 6 weeks by enzymatic methods using certified commercial kits (Pars Azmon, Iran) and LDL 
level calculated by the Friedewald's formula (LDL $=\mathrm{TC}-\mathrm{HDL}-\mathrm{TG} / 5.0(\mathrm{mg} / \mathrm{dL})$ ) [10].

\subsection{Statistical Analysis}

Statistical analyses were conducted using SPSS software version 16.0. At first Kolmogorov-Smironov test was used to evaluate the normality of data distribution. Statistical analyses were done by descriptive statistics. One way analyze of variance (ANOVA) test were used for figure out the mean change of differences in three groups. Post Hoc LSD test was done to show which groups differ from the rest. Data were presented as mean \pm standard deviation. Significance was considered to be $\mathrm{P}<0.05$. Results were given with their $95 \%$ CIs.

\section{Results}

Sixty out of 70 selected patients aged $47.5 \pm 9$ y were eligible to be included in the study and all of them (36 female and 24 male) successfully completed the study (Figure 1). The average body mass index (BMI) of participants was $31.78 \pm 5.41 \mathrm{~kg} / \mathrm{m}^{2}$. Baseline characteristics of the study participants are shown in Table 1. Dietary intakes of macronutrients and calorie were estimated at baseline and end of the study; no significant changes were observed during the intervention.

\subsection{Effects on Lipid Profile}

Changes in the lipid profile parameters were presented in Table 2. TG were significantly decreased after the intervention in GSO group $(\mathrm{P}=0.004)$. Significant differences were also found in mean change of TG differences among three groups $(\mathrm{P}=0.01)$. Post Hoc test were shown these differences were significant between control and OO groups and also control and GSO groups ( $\mathrm{P}=0.02$ and 0.004 , respectively). It means that TG was significantly decreased in OO and also GSO groups. Differences in the mean change of other parameters of lipid profile were not significant $(\mathrm{P}>0.05)$.

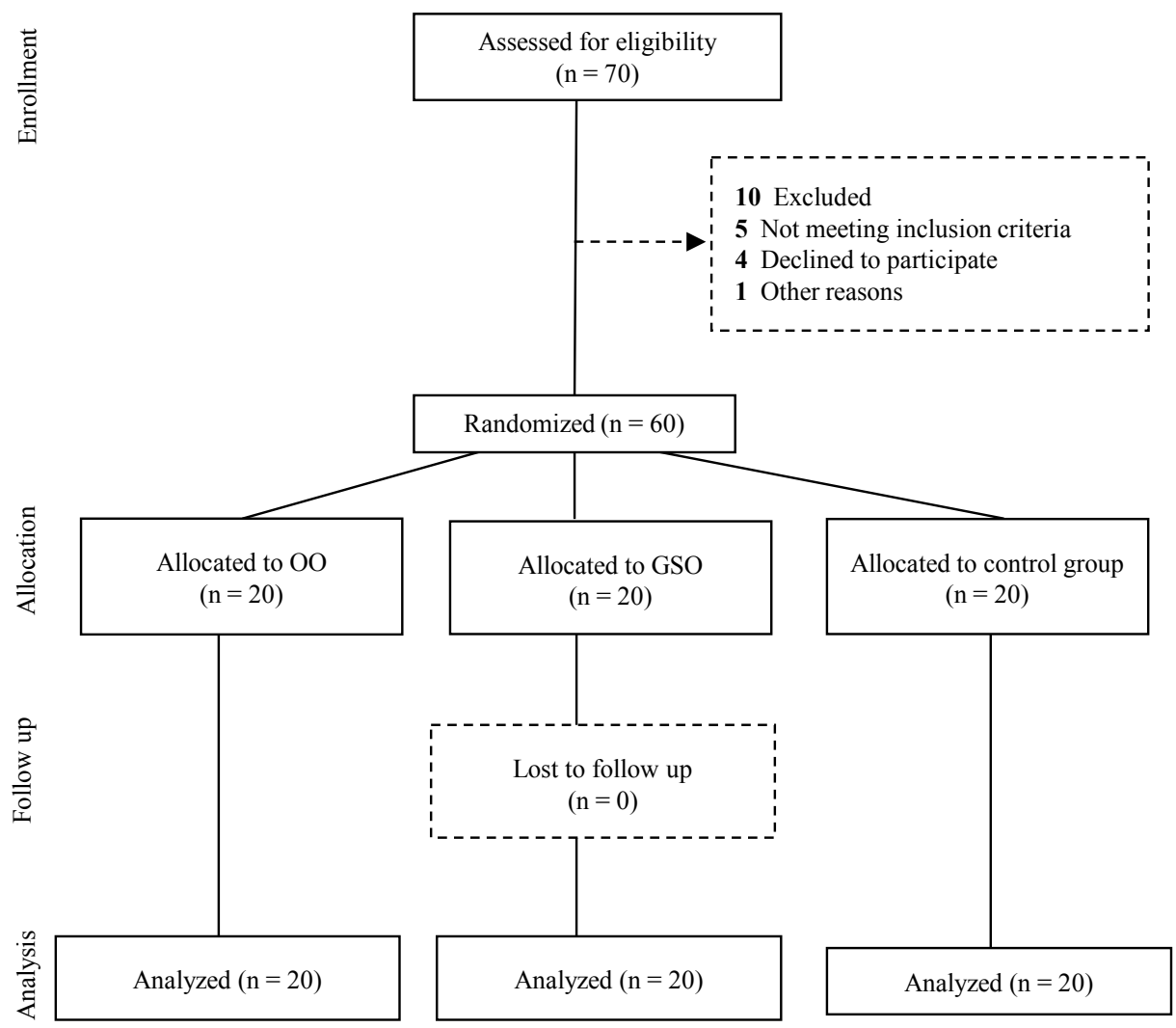

Figure 1. Flow of participants through each stage of this randomized trial. OO indicates Olive Oil group and GSO, grape seed oil group. 
Table 1. Baseline characteristics of patients in three groups.

\begin{tabular}{ccccc}
\hline \multirow{2}{*}{ Table Head } & \multicolumn{4}{c}{ Groups } \\
\cline { 2 - 5 } & Control & Olive oil & Grape seed oil & $\mathrm{p}^{\mathrm{b}}$ \\
\hline Age (year) & $47.10 \pm 8.23^{\mathrm{a}}$ & $48.45 \pm 8.78$ & $47.05 \pm 10.31$ & 0.86 \\
Weight $(\mathrm{kg})$ & $161.75 \pm 9.60$ & $160.37 \pm 8.22$ & $160.29 \pm 6.20$ & 0.81 \\
Height $(\mathrm{cm})$ & $85.60 \pm 19.76$ & $76.75 \pm 13.23$ & $84.52 \pm 19.63$ & 0.26 \\
BMI $\left(\mathrm{kg} / \mathrm{m}^{2}\right)$ & $48.29 \pm 38.55$ & $28.34 \pm 1.96$ & $36.92 \pm 5.27$ & 0.15 \\
\hline
\end{tabular}

${ }^{\mathrm{a}}$ Mean \pm SD. ${ }^{\mathrm{b}}$ One way ANOVA test.

Table 2. Changes in lipid profile parameters of 3 study groups through the intervention.

\begin{tabular}{|c|c|c|c|c|c|}
\hline \multirow{2}{*}{ Table Head } & & \multicolumn{4}{|c|}{ Groups } \\
\hline & & Control & Olive oil & Grape seed oil & $\mathrm{P}^{\mathrm{c}}$ \\
\hline \multirow{4}{*}{$\begin{array}{c}\mathrm{TG} \\
(\mathrm{mg} / \mathrm{dl})\end{array}$} & Before & $246.50 \pm 167.73^{\mathrm{a}}$ & $271.90 \pm 112.86$ & $262.30 \pm 104.95$ & 0.82 \\
\hline & After & $292.30 \pm 197.02$ & $225.35 \pm 67.59$ & $190.70 \pm 118.82$ & 0.07 \\
\hline & Change & $45.80 \pm 122.42$ & $-46.55 \pm 149.46$ & $-71.60 \pm 97.10$ & 0.01 \\
\hline & $P$-value ${ }^{b}$ & 0.11 & 0.18 & 0.004 & \\
\hline \multirow{4}{*}{$\begin{array}{c}\mathrm{TC} \\
(\mathrm{mg} / \mathrm{dl})\end{array}$} & Before & $205.75 \pm 41.85$ & $214.70 \pm 33.31$ & $211.05 \pm 31.58$ & 0.73 \\
\hline & After & $204.00 \pm 35.39$ & $204.35 \pm 30.62$ & $203.25 \pm 26.97$ & 0.99 \\
\hline & Change & $-1.75 \pm 57.16$ & $-11.45 \pm 36.30$ & $-6.70 \pm 24.17$ & 0.76 \\
\hline & P-value ${ }^{*}$ & 0.89 & 0.17 & 0.23 & \\
\hline \multirow{4}{*}{$\begin{array}{c}\text { LDL } \\
(\mathrm{mg} / \mathrm{dl})\end{array}$} & Before & $120.00 \pm 28.00$ & $121.7 \pm 17.54$ & $119.72 \pm 28.43$ & 0.96 \\
\hline & After & $118.30 \pm 23.42$ & $112.69 \pm 23.35$ & $120.62 \pm 34.29$ & 0.68 \\
\hline & Change & $-3.73 \pm 38.00$ & $-9.80 \pm 21.60$ & $-2.31 \pm 16.27$ & 0.68 \\
\hline & P-value ${ }^{*}$ & 0.67 & 0.06 & 0.57 & \\
\hline \multirow{4}{*}{$\begin{array}{c}\text { HDL } \\
(\mathrm{mg} / \mathrm{dl})\end{array}$} & Before & $14.86 \pm 3.32$ & $6.14 \pm 1.37$ & $10.78 \pm 2.41$ & 0.33 \\
\hline & After & $42.50 \pm 11.25$ & $42.11 \pm 9.11$ & $46.39 \pm 15.95$ & 0.51 \\
\hline & Change & $-1.65 \pm 7.46$ & $2.78 \pm 8.42$ & $1.22 \pm 13.41$ & 0.37 \\
\hline & P-value ${ }^{*}$ & 0.33 & 0.16 & 0.70 & \\
\hline
\end{tabular}

${ }^{\mathrm{a}}$ Mean \pm SD. ${ }^{\mathrm{b}}$ Paired t-test. ${ }^{\mathrm{c}}$ ANOVA.

\subsection{Effects on BP and FBS}

Changes in the BP and FBS were presented in Table 3. Systolic blood pressure (SBP) was significantly decreased after intervention in $O O$ group $(\mathrm{P}<0.001)$. Significant differences were also found in mean change of SBP differences among three groups of study $(\mathrm{P}=0.04)$. Post Hoc LSD test were shown this differences was between OO and GSO groups $(\mathrm{P}=0.01)$. It means that olive oil intervention decreased SBP significantly compared to GSO group. The mean of diastolic blood pressure (DBP) before and after the study were significant between groups. So we adjust its effect by Univariate Analysis of Variances. The mean of DBP were significantly decreased in $\mathrm{OO}$ and control groups $(\mathrm{P}<0.05)$ but Univariate Analysis of Variances showed these reductions in DBP were not significant $(\mathrm{P}=0.23)$.

Differences in the mean change of FBS was not significant $(\mathrm{P}>0.05)$. 
Table 3. Changes in BP and FBS levels of 3 study groups through the intervention.

\begin{tabular}{|c|c|c|c|c|c|}
\hline \multirow{2}{*}{ Table Head } & & \multicolumn{4}{|c|}{ Groups } \\
\hline & & Control & Olive oil & Grape seed oil & $\mathrm{P}^{\mathrm{c}}$ \\
\hline \multirow{4}{*}{$\begin{array}{c}\mathrm{TG} \\
(\mathrm{mg} / \mathrm{dl})\end{array}$} & Before & $121.50 \pm 14.51^{\mathrm{a}}$ & $135.15 \pm 20.76$ & $112.90 \pm 29.61$ & 0.01 \\
\hline & After & $121.20 \pm 8.73$ & $124.20 \pm 15.13$ & $118.30 \pm 15.93$ & 0.39 \\
\hline & Change & $-0.30 \pm 29.85$ & $-10.95 \pm 15.73$ & $5.40 \pm 11.36$ & 0.04 \\
\hline & P-value & 0.93 & 0.000 & 0.42 & \\
\hline \multirow{4}{*}{$\begin{array}{c}\mathrm{TC} \\
(\mathrm{mg} / \mathrm{dl})\end{array}$} & Before & $87.25 \pm 4.993$ & $85.10 \pm 8.546$ & $79.45 \pm 8.388$ & 0.005 \\
\hline & After & $83.00 \pm 6.974$ & $78.75 \pm 8.717$ & $75.80 \pm 7.585$ & 0.018 \\
\hline & Change & $-4.250 \pm 6.679$ & $-6.350 \pm 7.734$ & $-3.650 \pm 9.016$ & 0.52 \\
\hline & P-value ${ }^{*}$ & 0.01 & 0.02 & 0.08 & \\
\hline \multirow{4}{*}{$\begin{array}{l}\text { LDL } \\
(\mathrm{mg} / \mathrm{dl})\end{array}$} & Before & $132.40 \pm 56.65$ & $210.10 \pm 271.33$ & $116.05 \pm 35.31$ & 0.15 \\
\hline & After & $132.25 \pm 58.73$ & $112.25 \pm 29.84$ & $123.80 \pm 50.51$ & 0.42 \\
\hline & Change & $-0.15 \pm 5.27$ & $-97.85 \pm 279.72$ & $7.75 \pm 22.14$ & 0.08 \\
\hline & P-value ${ }^{*}$ & 0.9 & 0.13 & 0.13 & \\
\hline
\end{tabular}

${ }^{\mathrm{a}} \mathrm{Mean} \pm \mathrm{SD} .{ }^{\mathrm{b}}$ Paired t- test. ${ }^{\mathrm{c}} \mathrm{ANOVA}$.

\section{Discussion}

In this study all three groups adhered Step I diet and they all have the same calorie intake. So it had same effect on three groups. In our study, consumption of OO reduced FBS compared with two other groups but this reduction was not significant and this is consistent with Madigan et al. [11] and Paniagua et al. [12] findings. They stated insulin sensitivity improvement as the cause of this effect. In addition, consumption of GSO increased FBS compared with control group insignificantly.

From the nutritional point of views, OO contains a high level $(70 \%-80 \%)$ of oleic acid that may lead to reducing triglycerides and raising HDL [13]. GSO has a high linoleic acid $(60 \%-75 \%)$ content and it is recognized that its intake may result in lipid profile refining [14].

In our study both OO and GSO were associated with a significant reduction in serum TG and this is in line with Burglund et al. [7] and Allman-Farinelli et al. [15] studies but Despites reports, No significant change occurred in other Lipid profiles after intervention in two oil groups [11] [15]-[17]. An explanation for the lack of significant effects on other lipid profiles is that fatty acids are not the only factors for the lipid lowering effect of these oils. For example, some studies affirm that the phenolic content of OO and GSO can account for more benefits on other lipid profiles than those provided by the fatty acid content [13] [18]. And this is Consistent with results obtained after phenolic-rich food consumption in other studies [19]. The insignificancy of the changes in the other lipid profile in our study could be the result of using refined oils with no phenolic content.

Reduction of TG in OO group is corresponded with reduction of FBS. Increased consumption of MUFAs improves insulin sensitivity and consequently reduce TG levels because Lipoprotein lipase, the enzyme responsible for the clearance of serum TG, is an insulin sensitive enzyme [20]. So oleic acid contrasts with some of the abnormalities in glucose and lipid metabolisms. This effect is not observed with receiving linoleic acid [21].

In comparison GSO and control group, that of OO intervention decreased SBP significantly. This observation can be supported by Bondia-pon et al. [22] Fito M et al. [23] and some other previous studies that demonstrated beneficial effects of consuming olive oil and other MUFA rich diets in blood pressure in healthy state, hypertension, coronary heart disease and Type 2 diabetes [24]-[26]. In Fito $\mathrm{M}$ et al. [23] study had more reduction after virgin olive oil administration than after refined olive oil administration. Ruiz-Gutierrez et al. [24] also attribute this reduction to minor olive oil components.

A major limitation of this study was finding people who met the inclusion criteria and have desire to participate in the study. 


\section{Conclusion}

Overall, in this study both OO and GSO had a significantly good effect on TG; OO had also good effect on SBP. So replacing olive oil in the diet is more salubrious than grape seed oil in patients with hyperlipidemia. Nevertheless, the need for more studies on the effects of these oils on inflammatory markers and oxidative stress is felt.

\section{Acknowledgements}

We thank Ms Golchehr Kiani, Ms Fariba Khoshkam and all the staff of Diabetes Research Center, Yazd, Iran. This work was funded by Diabetic Research Center, Shahid Sadoughi University of Medical Sciences, Yazd, Iran.

\section{Conflicts of Interest}

The authors have no conflicts of interest to declare.

\section{References}

[1] Hodgson, J.M., Wahlqvist, M.L. and Hsu-Hage, B. (1995) Diet, Hyperlipidaemia and Cardiovascular Disease. Asia Pacific Journal of Clinical Nutrition, 4, 304-313. http://apjen.nhri.org.tw/SERVER/APJCN/4/3/304.htm

[2] Krug, E.G., Mercy, J.A., Dahlberg, L.L. and Zwi, A.B. (2002) The World Report on Violence and Health. The Lancet, 360, 1083-1088. http://www.sciencedirect.com/science/article/pii/S0140673602111330

[3] Shidfar, Keshavarz, Jallali, Miri and Eshraghian (2003) Comparison of the Effects of Simultaneous Administration of Vitamin C and Omega-3 Fatty Acids on Lipoproteins, Apo AI, Apo B, and Malondialdehyde in Hyperlipidemic Patients. International Journal for Vitamin and Nutrition Research, 73, 163-170. http://econtent.hogrefe.com/doi/abs/10.1024/0300-9831.73.3.163

[4] Willett, W.C. (2006) The Mediterranean Diet: Science and Practice. Public Health Nutrition, 9, 105-110. http://journals.cambridge.org/action/displayAbstract?fromPage $=$ online\&aid $=585588 \&$ fileId $=$ s 1368980006000243

[5] Sirtori, C.R., Tremoli, E., Gatti, E., Montanari, G., Sirtori, M., Colli, S., et al. (1986) Controlled Evaluation of Fat Intake in the Mediterranean Diet: Comparative Activities of Olive Oil and Corn Oil on Plasma Lipids and Platelets in High-Risk Patients. The American Journal of Clinical Nutrition, 44, 635-642. http://ajcn.nutrition.org/content/44/5/635.short

[6] Binkoski, A.E., Kris-Etherton, P.M., Wilson, T.A., Mountain, M.L. and Nicolosi, R.J. (2005) Balance of Unsaturated Fatty Acids Is Important to a Cholesterol-Lowering Diet: Comparison of Mid-Oleic Sunflower Oil and Olive Oil on Cardiovascular Disease Risk Factors. Journal of the American Dietetic Association, 105, 1080-1086. http://www.sciencedirect.com/science/article/pii/S0002822305004839

[7] Berglund, L., Lefevre, M., Ginsberg, H.N., Kris-Etherton, P.M., Elmer, P.J., Stewart, P.W., et al. (2007) Comparison of Monounsaturated Fat with Carbohydrates as a Replacement for Saturated Fat in Subjects with a High Metabolic Risk Profile: Studies in the Fasting and Postprandial States. The American Journal of Clinical Nutrition, 86, 16111620. http://ajcn.nutrition.org/content/86/6/1611.short

[8] Ros, E. (2003) Dietary Cis-Monounsaturated Fatty Acids and Metabolic Control in Type 2 Diabetes. The American Journal of Clinical Nutrition, 78, 617S-625S.

http://ajen.nutrition.org/content/78/3/617S.full.pdf + html\&member=\&journal=ajcn\&volume=78\&issue number=3\&co ver date=September $\% 201$

[9] Kris-Etherton, P., Eckel, R.H., Howard, B.V., Jeor, S.S. and Bazzarre, T.L. (2001) Lyon Diet Heart Study Benefits of a Mediterranean-Style, National Cholesterol Education Program/American Heart Association Step I Dietary Pattern on Cardiovascular Disease. Circulation, 103, 1823-1825. http://circ.ahajournals.org/content/103/13/1823.short

[10] Friedewald, W.T., Levy, R.I. and Fredrickson, D.S. (1972) Estimation of the Concentration of Low-Density Lipoprotein Cholesterol in Plasma, without Use of the Preparative Ultracentrifuge. Clinical Chemistry, 18, 499-502. http://www.clinchem.org/content/18/6/499.short

[11] Madigan, C., Ryan, M., Owens, D., Collins, P. and Tomkin, G.H. (2000) Dietary Unsaturated Fatty Acids in Type 2 Diabetes: Higher Levels of Postprandial Lipoprotein on a Linoleic Acid-Rich Sunflower Oil Diet Compared with an Oleic Acid-Rich Olive Oil Diet. Diabetes Care, 23, 1472-1477. http://care.diabetesjournals.org/content/23/10/1472.short

[12] Paniagua, J.A., de la Sacristana, A.G., Sánchez, E., Romero, I., Vidal-Puig, A., Berral, F.J., et al. (2007) A MUFARich Diet Improves Posprandial Glucose, Lipid and GLP-1 Responses in Insulin-Resistant Subjects. Journal of the 
American College of Nutrition, 26, 434-444. http://www.tandfonline.com/doi/abs/10.1080/07315724.2007.10719633

[13] Covas, M.I. (2008) Bioactive Effects of Olive Oil Phenolic Compounds in Humans: Reduction of Heart Disease Factors and Oxidative Damage. Inflammopharmacology, 16, 216-218. http://link.springer.com/article/10.1007/s10787-008-8019-6\#/page-1

[14] Pardo, J.E., Fernández, E., Rubio, M., Alvarruiz, A. and Alonso, G.L. (2009) Characterization of Grape Seed Oil from Different Grape Varieties (Vitis vinifera). European Journal of Lipid Science and Technology, 111, 188-193. http://onlinelibrary.wiley.com/doi/10.1002/ejlt.200800052/abstract

[15] Allman-Farinelli, M.A., Gomes, K., Favaloro, E.J. and Petocz, P. (2005) A Diet Rich in High-Oleic-Acid Sunflower Oil Favorably Alters Low-Density Lipoprotein Cholesterol, Triglycerides, and Factor VII Coagulant Activity. Journal of the American Dietetic Association, 105, 1071-1079. http://www.sciencedirect.com/science/article/pii/S0002822305004827

[16] Hodson, L., Skeaff, C. and Chisholm, W.-A. (2001) The Effect of Replacing Dietary Saturated Fat with Polyunsaturated or Monounsaturated Fat on Plasma Lipids in Free-Living Young Adults. European Journal of Clinical Nutrition, 55, 908-915. http://dx.doi.org/10.1038/sj.ejcn.1601234

[17] Ródenas, S., Rodríguez-Gil, S., Merinero, M.C. and Sánchez-Muniz, F.J. (2005) Dietary Exchange of an Olive Oil and Sunflower Oil Blend for Extra Virgin Olive Oil Decreases the Estimate Cardiovascular Risk and LDL and Apolipoprotein AII Concentrations in Postmenopausal Women. Journal of the American College of Nutrition, 24, 361-369. http://www.tandfonline.com/doi/abs/10.1080/07315724.2005.10719486 http://dx.doi.org/10.1080/07315724.2005.10719486

[18] Weinbrenner, T., Fitó, M., de la Torre, R., Saez, G.T., Rijken, P., Tormos, C., et al. (2004) Olive Oils High in Phenolic Compounds Modulate Oxidative/Antioxidative Status in Men. The Journal of Nutrition, 134, 2314-2321. http://jn.nutrition.org/content/134/9/2314.short

[19] Mursu, J., Voutilainen, S., Nurmi, T., Rissanen, T.H., Virtanen, J.K., Kaikkonen, J., et al. (2004) Dark Chocolate Consumption Increases HDL Cholesterol Concentration and Chocolate Fatty Acids May Inhibit Lipid Peroxidation in Healthy Humans. Free Radical Biology and Medicine, 37, 1351-1359. http://www.sciencedirect.com/science/article/pii/S0891584904004551 http://dx.doi.org/10.1016/j.freeradbiomed.2004.06.002

[20] Berry, E.M. (1997) Dietary Fatty Acids in the Management of Diabetes Mellitus. The American Journal of Clinical Nutrition, 66, 991S-997S. http://ajcn.nutrition.org/content/66/4/991S.short

[21] Heine, R., Mulder, C., Popp-Snijders, C., Van der Meer, J. and Van der Veen, E. (1989) Linoleic-Acid-Enriched Diet: Long-Term Effects on Serum Lipoprotein and Apolipoprotein Concentrations and Insulin Sensitivity in NoninsulinDependent Diabetic Patients. The American Journal of Clinical Nutrition, 49, 448-456.

http://ajcn.nutrition.org/content/49/3/448.short

[22] Bondia-Pons, I., Schröder, H., Covas, M.-I., Castellote, A.I., Kaikkonen, J., Poulsen, H.E., et al. (2007) Moderate Consumption of Olive Oil by Healthy European Men Reduces Systolic Blood Pressure in Non-Mediterranean Participants. The Journal of Nutrition, 137, 84-87. http://jn.nutrition.org/content/137/1/84.short

[23] Fito, M., Cladellas, M., De La Torre, R., Marti, J., Alcantara, M., Pujadas-Bastardes, M., et al. (2005) Antioxidant Effect of Virgin Olive oil in Patients with Stable Coronary Heart Disease: A Randomized, Crossover, Controlled, Clinical Trial. Atherosclerosis, 181, 149-158. http://www.sciencedirect.com/science/article/pii/S0021915005000456 http://dx.doi.org/10.1016/j.atherosclerosis.2004.12.036

[24] Ruiz-Gutierrez, V., Muriana, F.J., Guerrero, A., Cert, A.M. and Villar, J. (1996) Plasma Lipids, Erythrocyte Membrane Lipids and Blood Pressure of Hypertensive Women after Ingestion of Dietary Oleic Acid from Two Different Sources. Journal of Hypertension, 14, 1483-1490. http://journals.lww.com/jhypertension/Citation/1996/12000/Plasma lipids, erythrocyte membrane lipids and.16.aspx http://dx.doi.org/10.1097/00004872-199612000-00016

[25] Psaltopoulou, T., Naska, A., Orfanos, P., Trichopoulos, D., Mountokalakis, T. and Trichopoulou, A. (2004) Olive Oil, the Mediterranean Diet, and Arterial Blood Pressure: The Greek European Prospective Investigation into Cancer and Nutrition (EPIC) Study. The American Journal of Clinical Nutrition, 80, 1012-1018. http://ajcn.nutrition.org/content/80/4/1012.short

[26] Rasmussen, O.W., Thomsen, C., Hansen, K.W., Vesterlund, M., Winther, E. and Hermansen, K. (1993) Effects on Blood Pressure, Glucose, and Lipid Levels of High-Monounsaturated Fat Diet Compared With a High-Carbohydrate Diet in NIDDM Subjects. Diabetes Care, 16, 1565-1571. http://care.diabetesjournals.org/content/16/12/1565.short http://dx.doi.org/10.2337/diacare.16.12.1565 


\section{Submit or recommend next manuscript to SCIRP and we will provide best service for you:}

Accepting pre-submission inquiries through Email, Facebook, Linkedin, Twitter, etc A wide selection of journals (inclusive of 9 subjects, more than 200 journals)

Providing a 24-hour high-quality service

User-friendly online submission system

Fair and swift peer-review system

Efficient typesetting and proofreading procedure

Display of the result of downloads and visits, as well as the number of cited articles

Maximum dissemination of your research work

Submit your manuscript at: http://papersubmission.scirp.org/ 